\title{
Attitude and Motivation Towards English Language Learning of Freshman University Students
}

\author{
LUZVIMINDA P. ABDUL
}

Ipabdul@universityofbohol.edu.ph

https://orcid.org/0000-0001-5655-6217

JOSEFINA M. ALAS

jmalas@universityofobohol.edu.ph

https://orcid.org/0000-0003-4410-5210

JANE PRINCESS C. DAPLIN

princessmehjane@yahoo.com

https://orcid.org/0000-0003-2576-7307

MA. DOVY S. HERNANDO

mavyhernalina01@gmail.com

https://orcid.org/0000-0002-9880-0465

HERBERT A JUATON

hjuaton20@gmail.com

https://orcid.org/0000-0002-6044-3124

BERNADETTE T. RAÑIN

bernaranin7@gmail.com

https://orcid.org/0000-0001-9942-1822

KRISTEL FAYE R. ROSAS

kristelfaye9898@gmail.com

https://orcid.org/0000-0002-9895-7833

\section{J-ELSON G. URSOS}

jayelson@yahoo.com

https://orcid.org/0000-0002-1512-3957 


\begin{abstract}
The first year students from the different colleges taking the subject Purposive Communication in the second semester of the school year 2018-2019 were the respondents of this study. The study further sought to find out the perceived level of attitude and motivation of the respondents in the aspects of integrative and instrumental motivation. The study utilized the quantitative descriptive method, and the process of data collection was done through an adopted and modified questionnaire. The respondents answered the three-part questionnaire under the guidance of the researchers. The results of the study disclosed a composite mean of 3.11, described as High Motivation which indicates that respondents were of a high level of integrative motivation towards learning the English language. Moreover, the level of instrumental motivation had the composite mean of 3.29 with the interpretation of "Very High Motivation," which also signifies that students are motivated to study the language because of extrinsic motivation. The result further showed a direct relationship between students' attitude and motivation towards learning the English language. Hence, students are highly motivated because they have a positive attitude towards the language. Finally, the results indicated that there is no significant degree of difference between intrinsic and extrinsic motivation. Recommendations have been presented to enhance the students' level of interest in English language learning.
\end{abstract}

Keywords: Attitude, motivation, integrative, instrumental, English Language, Purposive Communication

\title{
INTRODUCTION
}

English is now a globally spoken language. Across Asia, the number of people having at least a functional command of the language has grown over the last decades. Current changes in the sociolinguistic realities of the region are often rapid that it is difficult for an academic commentator to keep pace. The contemporary visibility and importance of English language throughout the Asian region coupled with the emergence and development of distinct varieties of Asian English have played an important part in the global history of English (Bolton, 2008). 
English has been part of the different areas of discipline in the Philippine educational system until now. Filipino learners of English immerse themselves in learning the language in order to achieve good performance in school. Learning the English language in the Philippines has been on the highlight for many years. English as a second language has a major concern in the Philippines due to its advantage towards landing a job particularly in English-speaking countries. Learning English cannot be done passively, but is achieved through active practice, guided repetition, and correction. Moreover, one's attitude and motivation also matters.

Attitude is one of the significant factors in language learning success and performance and receives considerable attention from both L1 (First Language) and L2 (Second Language). Students' attitudes on learning determine their willingness and ability to learn. According to Almahli (2007), attitude, in the framework of language learning, has different definitions and viewpoints depending on how it is used in context. Further, Montano and Kasprzyk (2008) explained that based on the theory of planned behaviour, the individual's belief about outcomes or attributes of performing the behaviour will determine one's attitude. Hence, a person who embraces a sturdy belief about definitely valued outcomes will eventually produce a positive attitude toward the behaviour and vice versa.

Additionally, Motivation is also considered an essential factor that influences language learning success. It has several effects on students' learning and behaviour. First, motivation directs behaviour toward particular goals. Second, motivation will increase students' time on a task and is also an important factor affecting their learning and achievement. Motivation, according to Dornyei (1998) as cited by Chalak, and Kassaian (2010) is vital to learning. It is an impulse, a necessity, a purpose, a yearning and an inner source that entails a person to do a particular action. It is further viewed as one of the principal features that impact the speed and amount of success to EFL learners.

Motivation is identified into two distinct orientations, namely integrative orientation and instrumental orientation, in integrative orientation; learners demonstrate interest in learning a second language to become integrated into the society of the target language and or to better understand the culture, tradition, and community of the people who speak that language. Motivation to learn a second language stems from positive feelings toward the community that speaks that language (Dornyei, 2001), This type of 
motivation is defined by Deci and Ryan (1985) as intrinsic motivation in which learners find enjoyment and interest in learning a language with a positive attitude.

An instrumental orientation or extrinsic motivation on the other hand, refers to the learning of a second language for pragmatic gains such as passing examinations or university requirements, obtaining a prospective career with lucrative income, or for further education overseas. Gardner(1985) defines instrumental motivation as "learning a language because of some more or less clearly perceived utility it might have for the learner." The learner desires to learn the language in order to accomplish some non-interpersonal purpose. He is motivated by external factors such as appraisal, gratification, pledge, or money to compel them towards accomplishment without realizing their genuine interest. They perform mainly for the attainment of a desired external reward.

This particular study aimed to find out the relationship between attitude and motivation on English language learning among the freshmen of the University of Bohol, $2^{\text {nd }}$ semester of School Year 2018-2019.

This study is anchored on the Motivation theory of Gardner (1985) which stated that motivation in learning a foreign language is a combination of elements that includes desire, positive attitude, and effort toward the language. Furthermore, he added that attitudes are components of motivation. It is a combination of effort and desire to achieve the goals of learning. He stated that motivation is a multi-faceted construct that has cognitive, affective, and behavioral components in which students who are motivated strive to achieve their goals in attaining their objectives. Moreover, he viewed motivation as the basic factor which has greatly influenced the students' success or failure while learning the second language.

The Self-Determination Theory as an approach to human motivation and personality uses traditional empirical methods while employing an organismic meta theory that highlights the importance of humans' evolved inner resources for personality development and behavioral selfregulation (Ryan, Kuhl, \& Deci, 1997).In this theory, Ryan and Deci (2000) distinguished the different types of motivation based on goals that give rise to actions and distinct reasons. Self-determination is the most fundamental selection between extrinsic and intrinsic motivations. Intrinsic motivation is doing something because the task is basically interesting or enjoyable while extrinsic motivation is doing something because the task leads to 
separable outcomes. Its arena is the investigation of people's inherent growth tendencies and innate psychological needs that are the bases for their self-motivation and personality integration. These are identified as the needs for competence (Deci, Vallerand, Pelletier, \& Ryan, 1991) that appear to be essential for facilitating optimal functioning of the natural propensities for growth and integration, as well as for constructive social development and personal well-being. In order to be self-determined, one should experience a sense of choice in regulating and initiating one's own actions.

The Cognitive Learning Theory of Gagne (1972) stated that there are five major categories of learning process. These are motor skills, verbal information, intellectual skills, cognitive strategies, and attitudes. Studies on school learning suggested that generalizations about critical learning conditions and outcomes can be made inside these categories but not between them.

Several studies were conducted related to this investigation. Lucas, Pulido, Miraflores, Ignacio, Tacay, and Lao (2010) conducted a study among selected college freshmen students from DLSU-Manila, San Beda College, Philippine Normal University, University of Sto. Tomas, Far Eastern University and Rogationist Seminary showed that freshmen are integratively motivated to learn specific language skills such as speaking and reading in the English language.

Al Mamun, Rahman, Rahman, and Hossaim's (2012) study on students' attitudes towards English in Life Science School of Khulna University in Khulna, Bangladesh reported that the respondents have positive attitudes towards English. The students like the English language because they recognize the significance of the language in this era of globalization and communication network.

Moreover, a study conducted by Ahmed, 2015 among undergraduate EFL Learners indicated an extremely positive attitude towards English language learning as shown in the results of the qualitative analysis; however, students had negative feelings or fear in connection to their classroom instruction experience

Additionally, Javid, Al-Asmari, and Farooq (2012) studied Saudi undergraduates' motivational orientations towards English language learning and found that the students bear stronger instrumental motivational orientations along with high preference for the intrinsic orientations as well. The medical students have the highest level of motivation among the 
respondents of the study.

Shirbagi (2010) further studied Iranian undergraduate students' attitudes and motivations towards English language acquisition and found that Iranian students learn the English language for its utilitarian value. The respondents showed positive attitude towards learning English. Majority of them preferred to spend much of their time on English subjects.

Likewise, Fatiha, Sliman, Mustapha, and Yahia (2014) from the University of Bechar, Algeria conducted a study on attitudes and motivations in learning English as a foreign language and concluded that both attitudes and motivation have deep impact on students towards the target language. Their motivation influences their attitudes towards language learning.

Eventually, Zhao (2015) studied the influence of learners, motivation, and attitudes on second language teaching and found out that in order to attain effective language teaching, the teacher should listen to the emotional aspect of the students. Motivation and attitude measure the foremost typically mentioned emotional aspect. They play an important role in English language learning. Students' learning interest is often boosted by enhancing their positive emotional experiences. With respect to the individual emotional reactions, it is appropriate for the teacher to require humanistic measures to discard the students' negative emotional experiences and develop their positive learning attitudes. Furthermore, learner-centered learning is presumed to be increased by peaceful classroom relationships between lecturers and learners by guaranteeing that the learners' affective demand be contemplated. A teacher's concern, encouragement, and rewards add weight to developing students' learning capacity.

\section{METHODOLOGY}

To attain the objective of this study, the quantitative descriptive method was used with the aid of a questionnaire adopted from the study of Adidin, Pour- Mohammadi, and Alzwari (2012) and another adopted questionnaire from Nakhon Kitjaroonchai (2012) in the study of motivation. Both questionnaires were modified to make it suitable to the setting of the respondents.

The respondents of this study were randomly selected first year college students of the University of Bohol who were enrolled in Purposive 
Communication during the $2^{\text {nd }}$ semester of the school year 2018-2019. A target of 30 percent was taken from the population or a total of 460 students represented all departments.

This study made use of two adopted instruments modified by the researchers. The Attitude test from the study of Adidin et al. (2012) was made up of 9 items and the Motivation test which consisted of 16 items lifted from the study of Nakhon Kitjaroonchai (2012). The respondents rated the statements by putting check marks on the space provided. These were categorized as strongly agree, agree, moderately agree, and disagree with the weight equivalence of $4,3,2,1$.

To ensure the validity of the instrument, the questionnaires were pretested to ten students who were not part of the study. Right after piloting the questionnaire to check for the reliability and validity, (the Cronbach's Alpha of 0.76 for 9 items in Attitude and 16 items in Motivation), slight corrections. The distribution of the tool followed after obtaining their consent.

\section{RESULTS AND DISCUSSION}

Profile of the College First Year Students. There were one hundred thirty-eight college freshmen who responded in this study, of which one hundred seven (77.54\%) were females and thirty-one $(22.46 \%)$ were males. Majority of them were at ages $18-19$ years old and mostly belonged to the different departments of the university, the greater participants were from the College of Business and Accountancy and the Teachers College.

Perceived Attitude of the Students towards English Language. Items 1 and 5 - "I feel proud when studying English language" and "I pay attention when studying English" had the highest weighted mean of 3.12 which is interpreted as Good.

This finding of the study contradicted with results of the investigation of Abidin (2012) in his study on students' attitudes towards learning English in terms of the behavioral, cognitive and emotional aspects. It revealed that Libyan secondary school students had negative attitude towards learning English. 
Table 1. Perceived Attitude of the Students towards English Language

\begin{tabular}{|c|c|c|c|c|}
\hline No. & Items & WM & 1 & $\mathrm{R}$ \\
\hline 1 & I feel proud when studying the English language. & 3.12 & G & 1.5 \\
\hline 2 & $\begin{array}{l}\text { I feel excited when I communicate in English with } \\
\text { others. }\end{array}$ & 2.87 & G & 6 \\
\hline 3 & $\begin{array}{l}\text { I feel confident in expressing my opinions/ideas/ } \\
\text { insights using the English language. }\end{array}$ & 2.68 & G & 8 \\
\hline 4 & I am participative in my English class discussion. & 2.67 & G & 9 \\
\hline 5 & I pay attention when studying English. & 3.12 & G & 1.5 \\
\hline 6 & $\begin{array}{l}\text { I have good emotions/feelings every time I attend my } \\
\text { English class. }\end{array}$ & 2.91 & G & 5 \\
\hline 7 & $\begin{array}{l}\text { I enjoy doing both oral and written activities in English. } \\
\text { (e.g. oral reporting, brainstorming, group discussion, } \\
\text { writing narratives, etc.) }\end{array}$ & 2.73 & G & 7 \\
\hline 8 & $\begin{array}{l}\text { I am interested in studying English; hence, I always } \\
\text { look forward to attend my English class. }\end{array}$ & 3.05 & G & 3 \\
\hline \multirow[t]{2}{*}{9} & $\begin{array}{l}\text { I feel enthusiastic to come to class when English is } \\
\text { being taught. }\end{array}$ & 2.94 & G & 4 \\
\hline & Composite Mean & 2.90 & Good & \\
\hline
\end{tabular}

Parameters: Rating

$1.0-1.74$ SD Strongly Disagree

$1.75-2.49 \mathrm{D}$ Disagree

$2.50-3.24$ A Agree

3.25 - 4.00 SA Strongly Agree
Interpretation

Poor

Fair

Good

Very Good

\section{Level of Motivation towards English Language}

Table 2 shows students' level of motivation towards English language. Their motivation towards learning English were sorted out as instrumental and integrative. Student's answers were categorized as follows: 4, Strongly Agree; 3, Agree; 2, Moderately Agree; and 1, Disagree.

The statement that generated the highest motivation level was Item 4 - "Helps me to better understand the ways of life of the people in the English speaking countries" which gained a mean of 3.24 with the interpretation of High Motivation. Meanwhile, Item 6 - "Helps me to associate with foreigners and learn about their values and beliefs" ranked the lowest having the weighted mean of 3.01 with the interpretation of High 
Motivation. A composite mean of 3.11 was generated with an interpretation of High Motivation level.

Analysis of the data revealed that the student-respondents have a high level of integrative motivation towards the English language. This means that students enrolled in Purposive Communication have great interest in learning the English language. This study corresponds to the results of the investigation made by Lucas et al. (2010) in a study conducted among selected college freshman students from several Philippine universities and colleges that showed that freshmen are integratively motivated to learn specific language skills such as speaking and reading in the English language.

\section{Table 2. Level of Motivation towards English Language}

$\begin{array}{lllll}\text { No. INTEGRATIVE MOTIVATION } & \text { WM } & \text { I } & \text { R }\end{array}$

Studying the English language is important to me because:

1 I can understand the culture and tradition of the British and American people.

$3.11 \mathrm{HM} \quad 4$

I can understand English stories, novels, and other literary works

$3.05 \mathrm{HM} \quad 8$

I can be able to participate more freely in activities among other groups which speak English.

$3.07 \mathrm{HM} \quad 6.5$

I can better understand the ways of life of the people in

the English speaking countries.

$3.24 \mathrm{HM} \quad 1$

5 I can easily make new friends from foreign places.

$3.09 \mathrm{HM} \quad 5$

6 I can associate with foreigners and learn about their values and beliefs.

$3.01 \mathrm{HM} \quad 9$

7 I can be an open-minded and friendly person.

$3.07 \mathrm{HM} \quad 6.5$

8 I can enjoy watching English news and movies.

$3.22 \mathrm{HM} \quad 2$

9 I can enjoy reading English books, articles, newspapers, and magazines.

$3.13 \mathrm{HM} \quad 3$

Composite Mean 


$\begin{array}{lll}\text { Parameters: } & \text { DV } & \text { Interpretation } \\ 1.0-1.74 \mathrm{D} & \text { Disagree } & \text { Low Motivation } \\ 1.75-2.49 \mathrm{MD} & \text { Moderately Agree } & \text { Average Motivation } \\ 2.50-3.24 \mathrm{~A} & \text { Agree } & \text { High Motivation } \\ 3.25-4.00 \mathrm{SA} & \text { Strongly AgreeVery } & \text { High Motivation }\end{array}$

Moreover, the instrumental motivation disclosed the following data; item 10 - "Is important to me because it will help me to get an ideal job in the near future" ranked the highest with the weighted mean of 3.53 with the interpretation of "Very High Motivation." While item 12 - "Is important to me because other people will recognize me more if I know a foreign language" ranked the lowest with the weighted mean of 3.05 with the interpretation of "High Motivation." The students' level of instrumental motivation towards the English language has a composite mean of 3.29 which is interpreted as "Very High Motivation."

This finding indicates that the students have a high level of instrumental motivation towards English language. It also shows that students are motivated to learn English because they are expecting something in return. Results of this study coincides with the investigation made by Ming, Ling, \& Jaafar (2011) who studied attitudes and motivations of Malaysian secondary students towards learning English as a second language and found that the students are generally more instrumentally motivated rather than integratively motivated. Majority of them learn a foreign language for their careers, fulfilment or graduation requirements, and additional knowledge

Table 3. Level of Motivation towards English Language (Instrumental Motivation)

\begin{tabular}{|c|c|c|c|}
\hline No. & INSTRUMENTAL MOTIVATION & I & $\mathrm{R}$ \\
\hline & Studying the English language is important to me because: & & \\
\hline 10 & It will help me to get an ideal job in the near future. & VHM & 1 \\
\hline 11 & It will make me a more knowledgeable person. & VHM & 3 \\
\hline 12 & $\begin{array}{l}\text { Other people will recognize me more if I know a foreign } \\
\text { language. }\end{array}$ & $\mathrm{HM}$ & 6 \\
\hline 13 & $\begin{array}{l}\text { It will help me easily search for information and materials in } \\
\text { English on the Internet. }\end{array}$ & $\mathrm{HM}$ & 5.5 \\
\hline 14 & It can help me when I work and travel abroad. & VHM & 2 \\
\hline 15 & It will help me achieve academically in school & $\mathrm{HM}$ & 5.5 \\
\hline 16 & I believe it is an important tool in our daily communication. & VHM & 4 \\
\hline
\end{tabular}


The perceived attitude of the first y ear s tudents t owards English Language has a composite mean of 2.90 which is interpreted as Good.

The level of students' integrative motivation has a composite mean of 3.11 which is interpreted as High Motivation while the level of students' instrumental motivation has a composite mean of 3.29 which is interpreted as Very High Motivation

Table 4. Summary of the perceived attitude and level of motivation of the students

\begin{tabular}{ccc}
\hline Variable & Composite Mean & Interpretation \\
\hline Attitude & 2.90 & Good \\
Integrative Motivation & 3.11 & High Motivation \\
Instrumental Motivation & 3.29 & Very High Motivation \\
\hline
\end{tabular}

Statistical analysis on the correlation between respondents' attitude and motivation, shows significant correlation, This clarifies that the students have a positive attitude towards English because they are motivated to learn the language.This supports the study of Fatiha et al. (2014) from the University of Bechar, Algeria who conducted a research on attitudes and motivations in learning English as a foreign language and concluded that both attitudes and motivation have deep impact on students towards the target language. Their motivation influences their attitudes towards language learning

Table 5. Significant degree of correlation between respondents' attitude and motivation

\begin{tabular}{ccc}
\hline Variable & Mean & Standard Deviation \\
\hline Attitude & 2.8986 & 0.3941 \\
Motivation & 3.1891 & 0.4775 \\
\hline
\end{tabular}

Computed $r=0.437$

Critical value of Pearson $r$ at $136 \mathrm{df}(0.05)=0.1685$

Result: Significant

$\mathrm{HO}_{1}$ : Rejected

Further, there was no significant degree of difference between integrative motivation and instrumental motivation. 


\section{CONCLUSIONS}

Here are the conclusions based on the results and findings:

1. The students' attitude towards the English language falls under the category of Good. This finding means that they need to further cultivate their attitude towards English to reach the maximum level

2. The students have a higher level of instrumental motivation than integrative motivation which indicates that they study English because they aspire to become more equipped in their academic life confident that they will have a better job in the future

3. There is a direct relationship between students' attitude and motivation towards learning the English language. Hence, if the students have a positive attitude towards English, their level of motivation to learn the language increases.

\section{REFERENCES CITED}

Adidin, M.J.Z., Pour-Mohammadi, M., \& Alzwari, H. (2012). EFL student's attitudes towards learning English language: The case of Libyan secondary school students,Asian social science, 8(2), 119. Retrieved September 26, 2018, from https://bit.ly/2lkZPLF

Al Mamun, A., Rahman, M., Rahman, A. R., \& Hossaim, A. A. (2012). Students' attitudes towards

English: The case of life science school of Khulna University. International Review of Social Sciences and Humanities, 3(1), 200-209. Retrieved September 26, 2018, from https://bit.ly/2vuPdDB

Bolton, K. (2008). English in Asia, Asian Englishes, and the issue of proficiency. English Today, 24(2), 3-12.

Chalak, A., \& Kassaian, Z. (2010). Motivation and attitudes of Iranian undergraduate EFL students towards learning English. GEMA Online ${ }^{\circledR}$ Journal of Language Studies, 10(2). My Additional reference

Deci, E.L., Vallerand, R.J., Pelletier, L.G., and Ryan, R.M. (1991). Motivation and Education; The Self-determination Perspective. Educational Psychologist, 26 (3-4), 325-346. Retrieved December 17, 
2018, from https://bit.ly/2D26f0X

Fatiha, M., Sliman, B., Mustapha, B., \& Yahia, M. (2014). Attitudes and Motivations in Learning

English as a Foreign Language. International Journal of Arts \& Sciences, 7(3), 117-128. Retrieved March 6, 2019, from https://bit. ly/2SKdsaB

Gardner, R.C. (1985). Social Psychology and Second Language Learning; The Role of Attitudes and Motivation, Arnold. Retrieved March 6, 2019, from https://bit.ly/2TI7mTi

Javid, C. Z., Al-Asmari, A. R., \& Farooq, U. (2012). Saudi undergraduates' motivational orientations towards English language learning along gender and university major lines: A comparative study. European Journal of Social Sciences, 27(2), 283-300. Retrieved September 26, 2018, from https://bit.ly/2DIDNDS

Lucas, R. I., Pulido, D., Miraflores, E., Ignacio, A., Tacay, M., \& Lao, J. (2010). A study on the intrinsic motivation factors in second language learning among selected freshman students. Philippine ESL Journal, 4(1), 3-23. Retrieved September 26, 2018, from https://bit. $\mathrm{ly} / 2 \mathrm{Om} 0 \mathrm{X} 7 \mathrm{c}$

Ryan, R. M., Kuhl, J., \& Deci, E. L. (1997). Nature and autonomy: An organizational view of social and neurobiological aspects of self-regulation in behavior and development. Development and psychopathology, 9(4), 701-728. Retrieved from https://bit.ly/2my35fw.

Ryan, R. M., \& Deci, E. L. (2000). Self-determination theory and the facilitation of intrinsic motivation, social development, and well-being. American psychologist, 55(1), 68. Retrieved December 17, 2018, from https://bit.ly/2Fmdmne

Shirbagi, N. (2010). An exploration of undergraduate students' motivation and attitudes towards English language acquisition. Journal of Behavioural Sciences, 20(2), 1-14. Retrieved December 17, 2018, from https://bit.ly/2Cef7k5 
Zhao, L. (2015). The Influence of Learners' Motivation and Attitudes on Second Language Teaching. Theory and Practice in Language Studies, 5(11), 2333-2339. Retrieved September 26, 2018, from https://bit.ly/2JhgORa 